\title{
Effects of Light on Growth and Flowering of Rosa hybrids 'Mercedes'
}

\author{
Frank M. Maas and Edwin J. Bakx' \\ Research Institute for Agrobiology and Soil Fertility (AB-DLO), P. O. Box 14, 6700 AA Wageningen, \\ The Netherlands
}

Additional index words. blind shoots, blue light, dry weight partitioning, far-red light, light quality, photomorphogenesis, phytochrome, red light, Rosaceae, rose, spectral distribution, stem elongation

\begin{abstract}
Growth and flowering of shoots of 'Mercedes' rose was investigated as a function of the level and spectral quality of photosynthetic photon flux (PPF). Experiments were performed with single-shoot plants decapitated above the two most basal leaves with five leaflets. The development of the two lateral shoots emerging from the axillary buds of these leaves was studied for 4 to 6 weeks. To discriminate between the effects of irradiance and light quality, plants were grown in growth chambers in which PPF and its spectral composition could be controlled. At a photoperiod of 12 hours, the length, weight, and flowering of the shoots strongly increased with irradiance. The growth and number of flowering shoots were always higher for the uppermost than for the second shoot. At the highest PPF $\left(270 \mu \mathrm{mol}^{-2} \cdot \mathrm{m}^{-2} \cdot \mathrm{s}^{-1}\right)$, flowering occurred in $89 \%$ and $33 \%$ of the uppermost and second shoots, respectively. At an irradiance level of $90 \mu \mathrm{mol} \cdot \mathrm{m}^{-2} \cdot \mathrm{s}^{-1}, \mathrm{these}$ percentages were $6 \%$ and $0 \%$. Although length and dry weight of both types of shoots were significantly increased by reducing the amount of blue light at constant PPF, flower development was not affected. In a second experiment, plants grown in white light $(12 \mathrm{~h} /$ day $)$ received a short treatment with low-intensity red or far-red 'light at the end of each photoperiod. An end-of-day treatment with red light resulted in significantly more flowering shoots than far-red. The red far-red reversibility of this flowering response indicates the involvement of the photoreceptor phytochrome.
\end{abstract}

The production of cut roses strongly depends on the levels of irradiance in the greenhouse (Mor and Halevy, 1984; Zieslin and Moe, 1985). The effect of light on flower production in roses is 2fold. First, light affects the number of buds developing from the base of the plant and the remaining part of a branch after harvesting the rose flowers. Second, light influences flower development. Although initiation of the flower primordium is independent of light intensity and photoperiod (Horridge and Cockshull, 1974; Zieslin and Moe, 1985), further development of the flower may arrest under unfavorable light conditions and the flower bud may abort, resulting in a blind shoot. The quantity and quality of the light may affect vegetative and flower bud development.

The availability of assimilates is a major factor involved in the growth and flower development of rose shoots. Increased transport of assimilates to young shoots, either as a result of higher rates of photosynthesis (Cockshull, 1975; Khosh-Khui and George, 1977; Hand and Cockshull, 1979; Mortensen et al., 1992) or by a shift in assimilate partitioning (Zieslin and Halevy, 1976; Mor et al., 198 1), stimulated the growth and flower development of roses. Mor and Halevy (1984) demonstrated the importance of light in the partitioning of assimilates in roses. The amount of assimilates transported to a darkened shoot on a well-illuminated plant was significantly reduced compared to that of a similar shoot exposed to low light levels $\left(<11 \mu \mathrm{mol} \cdot \mathrm{m}^{-2} \cdot \mathrm{s}^{-1}\right)$ by fiber optics (Mor and Halevy, 1984). Red light proved to be more effective in stimulating the import of assimilates by a shoot than blue or far-red light. Shoots treated with low-intensity red light showed improved

Received for publication 19 Sept. 1994. Accepted for publication 1 Feb. 1995. These investigations were supported by the Commodity Board for Ornamental Horticultural Products and the Netherlands Agency for Energy and the Environment. We thank Daan Kuiper, Siebe van de Geijn, and Johan Bakker for critically reading the manuscript and their valuable contributions to the discussion. The cost of publishing this paper was defrayed in part by the payment of page charges. Under postal regulations, this paper therefore must be hereby marked advertisement solely to indicate this fact.

'Present address: Wageningen Agricultural Univ., Dept. of Food Science, Division of Food Chemistry and Microbiology, Bomenweg 2, 6703 HD Wageningen, The Netherlands. growth and flower development.

Growth and morphogenesis of greenhouse crops maybe controlled by specific changes in light quality brought about by selective screening of sunlight (Mortensen and Strømme, 1987; Rajapakse and Kelly, 1992) or by the use of specific artificial light sources (Warrington and Mitchell, 1976). An increase in blue content and the red to far-red (R : FR) of the light by filtering sunlight through a $\mathrm{CuSO}_{4}$ solution significantly reduced plant height. On the other hand, blue-deficient light such as the orange light emitted by sodium lamps and light with a R : FR < 1 stimulated stem elongation in several plant species (Meijer, 1959; Smith, 1994). The quality of light during the daily photoperiod and a short end-of-day (EOD) light treatment with red or far-red light following a white-light photoperiod may strongly affect plant development. EOD-R reduced and EOD-FR increased plant length in tobacco (Kasperbauer, 1971), radish (Proctor, 1973), and soybean (Kasperbauer et al., 1984). In soybean, photosynthate partitioning to the roots was stimulated by R, while FR increased partitioning to stems (Kasperbauer et al., 1984).

The objectives of the present study were to 1) investigate the effects of changes in light quality on growth and flower development of lateral shoots of Rosa $\times$ hybrida 'Mercedes' and 2) examine the possible use of specific light qualities to increase the production and quality of cut roses at low photosynthetic photon flux (PPF) levels. The main changes in light quality to which greenhouse roses in The Netherlands are exposed are the orange light of high-pressure sodium lamps used for supplemental lighting during winter, decreased R: FR ratios in the canopy during the entire photoperiod due to the selective filtering and reflecting of light by the leaves, and daily short-term decreases in R: FR during sunrise and sunset (Hughes et al., 1984). To simulate two of these light conditions, either the blue-content of PPF was decreased during the entire light photoperiod or the plants were exposed to FR at the end of each white-light photoperiod while maintaining PPF constant and at a level at which white light was insufficient for all shoots to fully develop a flower, a situation that is common in Dutch greenhouses during winter. 
Table 1. Photosynthetic photon flux (PPF), blue-light (B) fraction of PPF, ratio of red to far-red light (R : FR), and calculated phytochome equilibrium $\left(\varphi_{c}\right)$ of white, amber, orange, end-of-day red (EOD-R), and end-of-day far-red (EOD-FR) light. Wavelength intervals used to calculate B : PPF and R: FR were B, 400-500 nm, PPF, 400-700 nm, R, 600-700 nm, FR, 700$800 \mathrm{~nm}$.

\begin{tabular}{lccccc}
\hline \hline & White & Amber & Orange & EOD-R & EOD-FR \\
\hline PPF $\left(\mu \mathrm{mol} \cdot \mathrm{m}^{-2} \cdot \mathrm{s}^{-1}\right)$ & 130 & 130 & 130 & 4.5 & 14.4 \\
B : PPF & 0.18 & 0.04 & 0.02 & 0.01 & 0.06 \\
R:FR & 7.9 & 8.1 & 7.3 & 40 & 0.004 \\
$\varphi_{c}$ & 0.81 & 0.83 & 0.83 & 0.87 & 0.05 \\
\hline
\end{tabular}

Table 2. Effects of light quantity (PPF) and quality (spectral distribution) on the dry weight (g) of different parts of 'Mercedes' rose.

\begin{tabular}{|c|c|c|c|}
\hline \multirow{2}{*}{$\begin{array}{l}\begin{array}{l}\text { Plant } \\
\text { part }\end{array} \\
\text { Experiment } I^{y}\end{array}$} & \multicolumn{3}{|c|}{$\begin{array}{l}\text { Light } \\
\text { treatment }\end{array}$} \\
\hline & White 90 & White 180 & White 270 \\
\hline Upper shoot & $2.26 \mathrm{a} \pm 0.15$ & $5.89 \mathrm{~b} \pm 0.66$ & $7.20 \mathrm{~b} \pm 1.08$ \\
\hline Lower shoot & $1.96 \mathrm{a} \pm 0.23$ & $4.30 \mathrm{~b} \pm 0.70$ & $5.55 \mathrm{~b} \pm 0.63$ \\
\hline Primary wood & $1.22 \mathrm{a} \pm 0.07$ & $1.70 b \pm 0.38$ & $1.79 b \pm 0.14$ \\
\hline Roots & $1.01 \mathrm{a} \pm 0.12$ & $1.86 \mathrm{~b} \pm 0.20$ & $2.27 b \pm 0.36$ \\
\hline Total plant & $6.93 \mathrm{a} \pm 0.32$ & $14.40 \mathrm{~b} \pm 1.86$ & $17.50 \mathrm{~b} \pm 2.10$ \\
\hline Experiment $\mathrm{II}^{\mathrm{y}}$ & White 130 & Amber 130 & Orange 130 \\
\hline Upper shoot & $3.65 \mathrm{a} \pm 0.39$ & $4.35 \mathrm{ab} \pm 0.51$ & $4.44 b \pm 0.32$ \\
\hline Lower shoot & $3.28 \mathrm{a} \pm 0.35$ & $4.17 \mathrm{a} \pm 1.05$ & $3.86 \mathrm{a} \pm 0.68$ \\
\hline Primary wood & $0.99 \mathrm{a} \pm 0.10$ & $1.15 \mathrm{a} \pm 0.14$ & $0.93 \mathrm{a} \pm 0.22$ \\
\hline Roots & $1.56 \mathrm{a} \pm 0.19$ & $1.70 \mathrm{a} \pm 0.29$ & $1.80 \mathrm{a} \pm 0.13$ \\
\hline \multirow[t]{2}{*}{ Total plant } & $10.62 \mathrm{a} \pm 1.23$ & $12.99 \mathrm{a} \pm 2.47$ & $12.29 \mathrm{a} \pm 1.65$ \\
\hline & White 130 & White 130 & White 130 \\
\hline Experiment III $^{y, x}$ & $+E O D-R$ & $+E O D-R / F R$ & $+E O D-F R / R$ \\
\hline Upper shoot & $2.62 \mathrm{a} \pm 0.21$ & $2.98 \mathrm{a} \pm 0.21$ & $2.79 \mathrm{a} \pm 0.04$ \\
\hline Lower shoot & $1.97 \mathrm{a} \pm 0.24$ & $2.15 \mathrm{a} \pm 0.34$ & $2.16 \mathrm{a} \pm 0.37$ \\
\hline Primary wood & $0.94 \mathrm{a} \pm 0.06$ & $1.10 \mathrm{~b} \pm 0.05$ & $1.12 b \pm 0.08$ \\
\hline Roots & $1.16 \mathrm{a} \pm 0.03$ & $1.27 \mathrm{a} \pm 0.10$ & $1.21 \mathrm{a} \pm 0.09$ \\
\hline Total plant & $6.83 \mathrm{a} \pm 0.07$ & $7.53 \mathrm{a} \pm 0.59$ & $7.36 \mathrm{a} \pm 0.49$ \\
\hline
\end{tabular}

${ }^{\overline{ }}$ Weights were determined 6 weeks after the start of the light treatment and represent the means of three measurements with three plants in each ( \pm SD). Values of the same plant part within an experiment followed by different letters are significantly different $(t$ test, $\mathrm{P}<0.05)$.

Light quality and PPF $\left(\mu \mathrm{mol} \cdot \mathrm{m}^{-2} \cdot \mathrm{s}^{-1}\right)$ of treatments presented at top of columns.

'End-of-day (EOD) light treatment were given as $20 \mathrm{~min}$ red light (R), or as $10 \mathrm{~min}$ red followed by far-red (R/FR) or vice versa (FR/R).

Table 3. Effects of light quantity (PPF) and quality (special distribution) on the length and flower development of the upper and lower shoot of 'Mercedes' rose.

\begin{tabular}{|c|c|c|c|c|c|}
\hline \multicolumn{2}{|c|}{ Light treatment } & \multirow{2}{*}{\multicolumn{2}{|c|}{ Shoot length $(\mathrm{cm})^{y}$}} & & \\
\hline \multirow[b]{2}{*}{ Quality } & \multirow{2}{*}{$\begin{array}{c}\mathrm{PPF} \\
\left(\mu \mathrm{molm} \mathrm{m}^{-2} \cdot \mathrm{s}^{-1}\right)\end{array}$} & & & \multicolumn{2}{|c|}{ Shoots with flower } \\
\hline & & Upper & Lower & Upper & Lower \\
\hline \multicolumn{6}{|l|}{ Experiment I } \\
\hline White & 90 & $29.4 \mathrm{a} \pm 3.4$ & $27.9 \mathrm{a} \pm 3.9$ & 6 & 0 \\
\hline White & 180 & $41.0 \mathrm{~b} \pm 3.5$ & $39.0 \mathrm{~b} \pm 5.1$ & 78 & 22 \\
\hline White & 270 & $39.4 \mathrm{~b} \pm 2.6$ & $41.1 \mathrm{~b} \pm 5.7$ & 89 & 33 \\
\hline \multicolumn{6}{|l|}{ Experiment II } \\
\hline White & 130 & $38.3 \mathrm{a} \pm 4.2$ & $35.2 \mathrm{a} \pm 6.2$ & 56 & 33 \\
\hline Amber & 130 & $48.7 b \pm 3.8$ & $44.1 \mathrm{~b} \pm 8.5$ & 58 & 32 \\
\hline Orange & 130 & $55.0 \mathrm{c} \pm 5.3$ & $50.4 c \pm 6.0$ & 65 & 18 \\
\hline \multicolumn{6}{|l|}{ Experiment III } \\
\hline EOD-R & 130 & $35.8 \mathrm{a} \pm 4.0$ & $29.9 \mathrm{a} \pm 6.5$ & 42 & 18 \\
\hline EOD-R/FR & 130 & $43.1 \mathrm{~b} \pm 5.8$ & $38.6 \mathrm{~b} \pm 3.9$ & 15 & 2 \\
\hline EOD-FR/R & 130 & $37.6 \mathrm{a} \pm 4.2$ & $33.1 \mathrm{ab} \pm 5.1$ & 40 & 23 \\
\hline
\end{tabular}

${ }^{\overline{ }} \mathrm{PPF}$ represents the irradiance during the daily photoperiod. EOD-light treatments with R and FR as described in Tables 1 and 2.

${ }^{y}$ Length and flower development were determined 6 weeks after the start of the light treatment and represent the means of 9 (Expt. I), 18 (Expt. II), or 12 plants (Expt. III). Significant differences $(t$ test, $\mathrm{P}<0.05)$ in the lengths of shoots of similar stem position are indicated by different letters. 
plant growth chamber (Heraeus-Vötsch GmbH, Balingen, Germany): Each compartment contained two tanks with $130-\mathrm{dm}^{3}$ nutrient solutions in which 40 plants/tank were grown. At 1-week intervals during the 6-week growth period, three samples of three plants each were harvested randomly from 40 fixed and equally spaced positions per treatment, Plants were harvested $6 \mathrm{~h}$ after the beginning of the light period and divided into upper and lower shoot (either as a whole or divided into leaves and stem), stem tissue of the original cutting (referred to as primary wood), and roots. Dry weights were measured after lyophilization of the plant material at $-50 \mathrm{C}$ and 0.07 mbar.

\section{Results}

Effects of PPF on plant growth and development. The growth of the lateral shoots was strongly affected by the level of irradiance. Compared to plants grown for 6 weeks at $90 \mu \mathrm{mol} \cdot \mathrm{m}^{-2} \cdot \mathrm{s}^{-1}$, the dry weights of the upper shoot, lower shoot, primary wood, and roots of plants grown at $180 \mu \mathrm{mol} \cdot \mathrm{m}^{-2}-\mathrm{s}^{-1}$ were $2.6,2.2,1.4$, and 1.8 times higher, respectively (Table 2, Expt. I). For plants grown at 270 $\mu \mathrm{mol} \cdot \mathrm{m}^{-2} \cdot \mathrm{s}^{-1}$, these values were respectively $3.2,2.8,1.5$, and 2.2 . These data demonstrate that in both cases the order at which the different plant parts gained from the increase in PPF was upper shoot > lower shoot> roots > primary wood.

The length of the upper and lower shoots after a growth period of 6 weeks was significantly enhanced by an increase in PPF from 90-180 $\mu \mathrm{mol} \cdot \mathrm{m}^{-2} \cdot \mathrm{s}^{-1}$ (Table 3, Expt. I). No further stimulation of shoot elongation was observed if the level of PPF was increased from $180-270 \mu \mathrm{mol} \cdot \mathrm{m}^{-2} \cdot \mathrm{s}^{-1}$. The ratio of leaf to stem dry weight of the shoots, determined after a growth period of 4 weeks (Table 4), demonstrated that the partitioning of dry weight between leaf and stem tissue was not affected by the level of PPF.

The percentage of flowering shoots was enhanced the most by an increase in PPF from $90-180 \mu \mathrm{mol} \cdot \mathrm{m}^{-2} \cdot \mathrm{s}^{-1}$; increasing by $75 \%$ for the upper shoot and $25 \%$ for the lower shoot. Increasing PPF from $180-270 \mu \mathrm{mol} \cdot \mathrm{m}^{-2} \cdot \mathrm{s}^{-1}$ caused only an additional $10 \%$ more flowering shoots in both positions (Table 3, Expt. I).

Effects of light quality on plant growth and development. Changing the quality of light during the entire photoperiod and 6week growth period at equal PPF did not significantly affect total plant dry weight (Table 2, Expt. II). Although amber and orange light tended to increase total plant weight, only the dry weight of the uppermost shoot grown in orange light was significantly greater than that of the plants grown in white light. Elongation of both lateral shoots was significantly enhanced by decreasing the blue-light content of PPF. After 6 weeks of growth, both types of shoots of amber-and orange-grown plants were respectively about 10 and $16 \mathrm{~cm}$ longer than those of the white light-grown plants (Table 3, Expt. II). Amber and orange light-grown plants partitioned relatively more dry weight into stem than leaves compared to white light-grown plants, since their leaf stem dry weight ratio was significantly lower (Table 4, Expt. II). Amber and orange light did not significantly affect the number of flowering shoots per plant, although in orange light there was a small shift in flowering between the upper and lower shoots (Table 3, Expt. II).

An EOD treatment with R or FR did not affect the dry weights of shoots, primary wood, or roots (Table 2, Expt. III). However, ending the photoperiod with FR resulted in significant decreases in the ratio of leaf dry weight to stem dry weight of the upper and lower shoots (Table 4, Expt. III). The effect of FR was reversible by giving the plants a second brief irradiation with $\mathrm{R}$ directly after the FR treatment, suggesting the involvement of the photoreceptor phytochrome. Ending each photoperiod with a high R : FR (R or
FR followed by R) resulted in 1.7 times more flowering upper shoots and 9 times more flowering lower shoots than a low R: FR (Table 3, Expt. III). This negative effect of EOD-FR on flower development was also R reversible. After 6 weeks, EOD-FR of upper and lower shoots was significantly longer than that of EODR-treated plants (Table 3, Expt. III). As for leaf:stem ratio and flowering, this EOD-FR effect was also reversed by a subsequent EOD-R treatment.

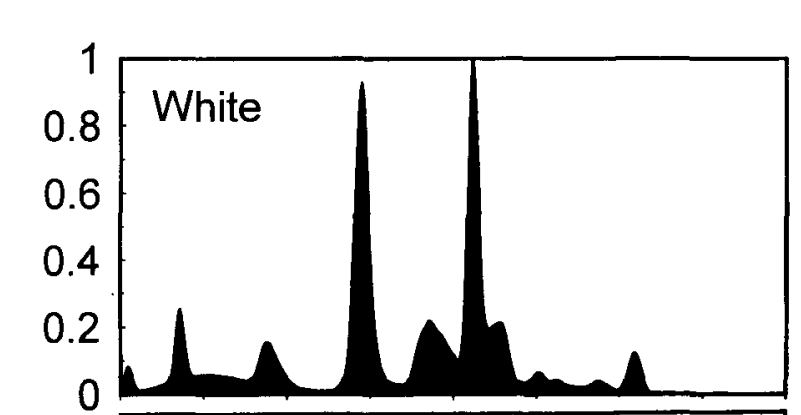

$x$
$\frac{3}{4}$
$\frac{0}{0}$
$\frac{0}{0}$
$\frac{0}{0}$
$\frac{\pi}{0}$
$\frac{0}{10}$
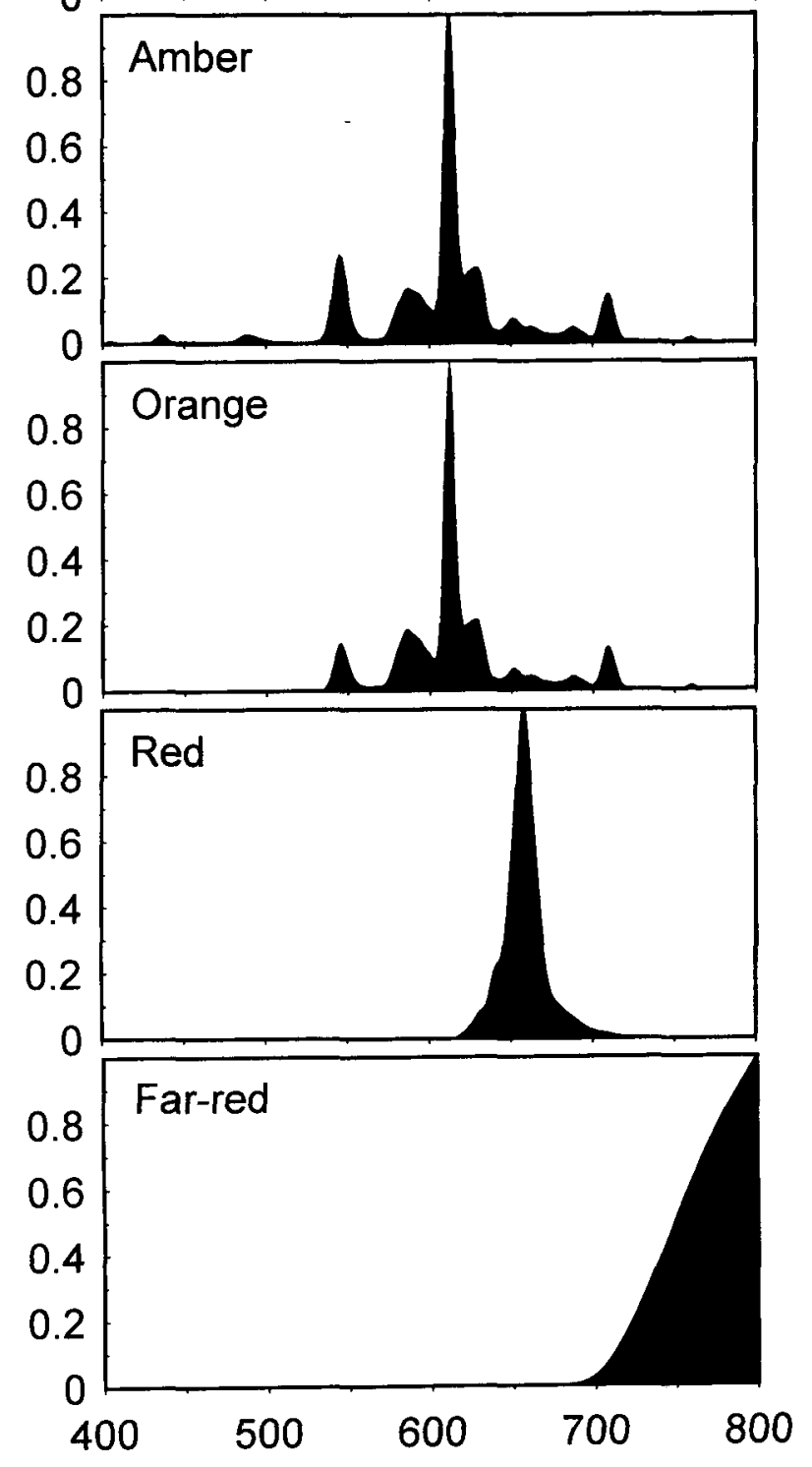

\section{Wavelength $(\mathrm{nm})$}

Fig. 2. Spectral photon distribution of white, amber, orange, red, and far-red light. 


\section{Materials and Methods}

Cultivation of rose plants. Rose shoots were obtained from a commercial rose grower. Single-node stem segments with a mature leaf (five leaflets) and about $2 \mathrm{~cm}$ stem above and $4 \mathrm{~cm}$ stem below the leaf joint were used as cuttings. Leaf and stem of the cutting were treated with $0.1 \%(\mathrm{w} / \mathrm{v})$ benlate and $10 \%(\mathrm{w} / \mathrm{v})$ captan, respectively, to prevent fungal growth. Rooting of the cuttings was promoted by placing their basal stem part into a $10 \mu \mathrm{M}$ solution of NAA (et-naphthaleneacetic acid) for $24 \mathrm{~h}$. After a 3week incubation at $25 \mathrm{C}$ in a $10 \%$ nutrient solution (Steiner, 1984) at a relative humidity (RH) of $>95 \%$ and $60 \mu \mathrm{mol} \cdot \mathrm{m}^{-2} \cdot \mathrm{s}^{-1} \mathrm{PPF}$ (58W/84 white fluorescent tubes; Philips, Eindhoven, NL) (14h/ day), $95 \%$ to $100 \%$ of the cuttings was rooted. The rooted cuttings were transferred to a full-strength Steiner's nutrient solution. The nutrient solution was replaced once a week. PPF in the plant growth chamber was increased to $270 \mu \mathrm{mol} \cdot \mathrm{m}^{-2} \cdot \mathrm{s}^{-1}$ (12 Malay), RH decreased to $70 \%( \pm 4 \%)$, and the day and night temperature changed to 20 and $18 \mathrm{C}( \pm 1 \mathrm{C})$. After 5-6 weeks, when the flower bud started to open, the shoot was decapitated above the two most basal mature leaves with five leaflets (Fig. 1). The original leaf from the cutting and any other leaves with less than five leaflets below the two upper leaves were removed and the light treatment was started. Only the axillary buds of the remaining leaves were allowed to develop into new shoots (Fig. 1). According to their position on the main stem, these shoots will be referred to as the upper shoot and lower shoot.

Lighting conditions. PPF (400-700 nm) at plant level was measured with a horizontally placed cosine corrected quantum sensor (LI-190SA; LI-COR, Lincoln, Neb.). A LI-1800 spectroradiometer was used to determine the spectral distribution or quality of the light from 400-800 nm at 1-rim intervals (Fig. 2). Light quality was characterized by the blue-light fraction of PPF(B : PPF) and by the ratio of red $(600-700 \mathrm{~nm})$ to far-red (700-800 $\mathrm{nm})$ light (R : FR). Extinction coefficients of rye phytochrome (Lagarias et al., 1987) and the spectral distribution of the light were used to calculate phytochrome equilibrium $\left(\varphi_{c}\right)$. Relevant spectral data of the light qualities used are summarized in Table 1.

Amber and orange light were obtained by filtering the light of the white fluorescent lamps through an amber or orange-colored cinemoid filter (filters 434 and 405, respectively; Strand Lighting Ltd, Isleworth, U.K.). These filters filtered out $85 \%$ (amber) or $100 \%$ (orange) of the blue light $(400-500 \mathrm{~nm})$ of the white lamps. End-of-day (EOD) FR was provided by incandescent lamps filtered through one layer of a red filter and one layer of a blue filter (Strand filters 406 and 419, respectively) and red light (R) by red " fluorescent tubes (TL 40W/16; Philips). EOD-light treatments were given directly at the end of the photoperiod period as $10 \mathrm{~min}$ $\mathrm{R}$ followed by $10 \mathrm{~min}$ FR, 10 min FR followed by $10 \mathrm{~min} \mathrm{R}$, or as $20 \mathrm{~min} \mathrm{R}$ (control). Photon fluxes at plant level were 14.4 $\mu$ mol.m-2.s-1 (700-800 nm) for the FR and $4.5 \mu \mathrm{mol} \cdot \mathrm{m}^{-2} \cdot \mathrm{s}^{-1}$ $(600-700 \mathrm{~nm})$ for the $\mathrm{R}$ treatment. The different photon fluxes for EOD-R and EOD-FR were chosen to reach $\varphi_{c}$ in the same time, . which was calculated to be $2.5 \mathrm{sec}$ for purified rye phytochrome (Lagarias et al., 1987).

Growth measurements and experimental design. All three successive experiments were started with 240 plants, which were divided equally over three $4.3-\mathrm{m}^{2}$ compartments within one $13-\mathrm{m}^{2}$

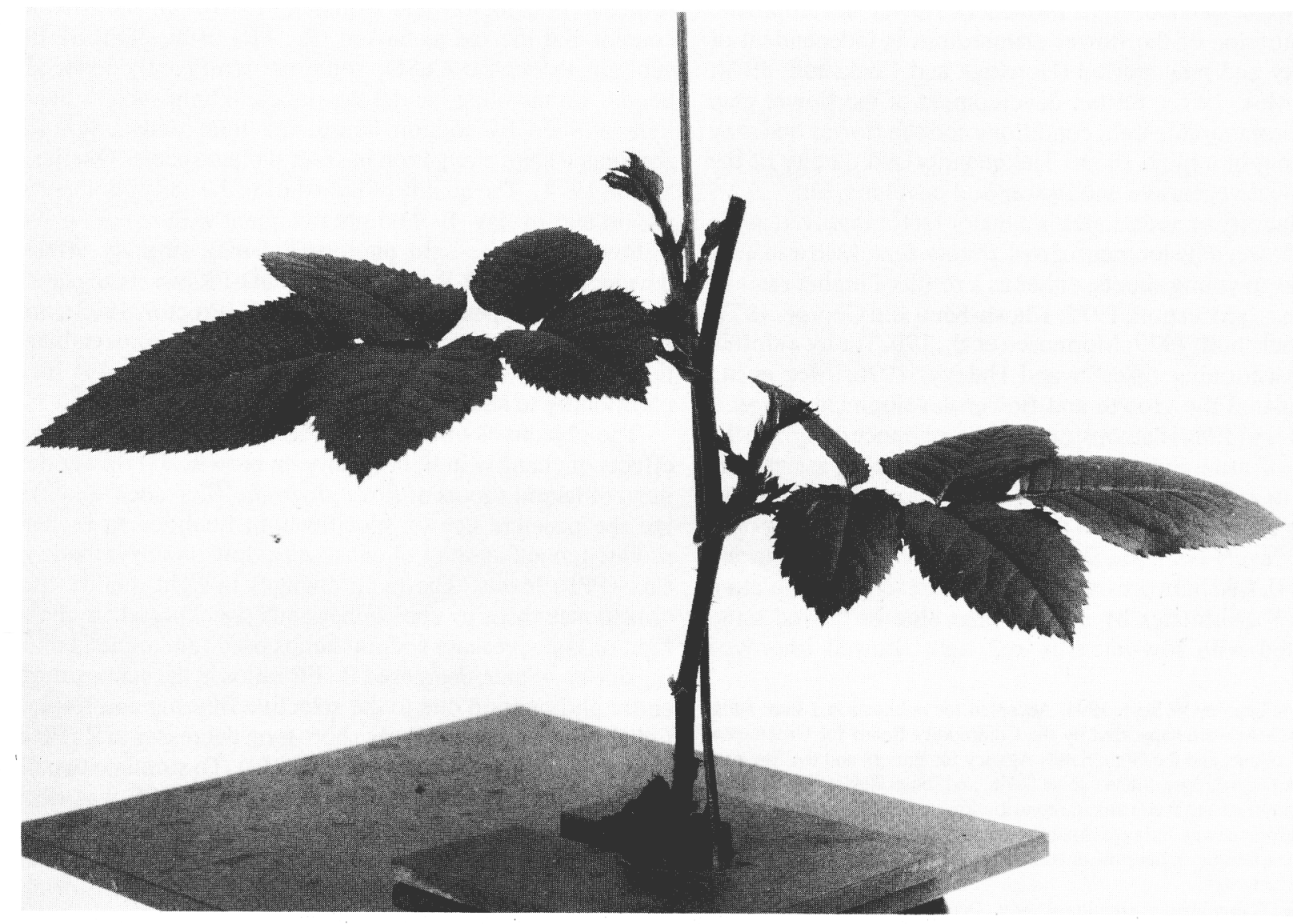

Fig. 1. 'Mercedes' rose about 10 days after pinning and the onset of the light treatment. 


\section{Discussion}

Our experiments with PPF of $90-270 \mu \mathrm{mol} \cdot \mathrm{m}^{-2} \cdot \mathrm{s}^{-1}(12 \mathrm{~h} /$ day $)$, representing average daily light sums in Dutch greenhouses from the middle of fall to the beginning of spring, showed that PPF levels below $180 \mu \mathrm{mol} \cdot \mathrm{m}^{-2} \cdot \mathrm{s}^{-1}$ were insufficient for most shoots to flower (Table 3). Changing the quality of the light at a PPF of 130 $\mu \mathrm{mol} \cdot \mathrm{m}^{-2} \cdot \mathrm{s}^{-1}$, at which in white light about $40 \%$ to $60 \%$ of the upper and $20 \%$ to $30 \%$ of the lower shoots flowered, resulted in substantial changes in shoot morphogenesis without significantly affecting total plant biomass. The length of the shoots, an important quality parameter for cut roses, was increased by decreasing the amount of blue in PPF without substantially affecting flower development of these shoots. Exposing 'Mercedes' rose to only an EOD-R (establishing the same $\varphi_{c}$, as white light in Expts. I and II) or EOD-FR pulse after a white-light photoperiod showed a similar effect of EOD-FR on shoot elongation and leaf:stem dry weight as amber and orange light (Table 4). However, contrary to the stimulation of shoot elongation by amber and orange light, the enhancement of shoot elongation by EOD-FR was accompanied by a significant reduction in flowering.

Potted miniature roses and chrysanthemums grown in sunlight filtered through a CuSO${ }_{4}$ solution (Rajapakse and Kelly, 1992, 1994), which increased the B : PFF and R : FR compared to unfiltered sunlight, showed comparable morphogenetic growth responses as 'Mercedes' rose in the present experiments: the shortest shoots were observed in plants grown in the light with the highest $\mathrm{B}$ : PPF and R: FR. As $\mathrm{CuSO}_{4}$ filters simultaneously alter $\mathrm{B}$ : PPF and $\mathrm{R}$ : FR, the effects of $\mathrm{CuSO}_{4}$-filtered light on stem elongation may have been mediated by phytochrome and a bluelight receptor. Independent control of stem elongation by phytochrome and a blue-light receptor has been reported for several plant species (Thomas and Dickinson, 1979; Gaba and Black, 1983; Smith, 1994). Our experiments with 'Mercedes' rose, in which $\mathrm{B}$ : PPF and R : FR were altered independently, clearly demonstrate that changes in $\mathrm{B}$ : PPF may affect stem elongation independent from changes in phytochrome equilibrium. As the phytochrome equilibria calculated for white, amber, and orange light were very similar $\left(\varphi_{c}=0.87\right.$, Table 1$)$ while B : PPF was 4.5 to 9 times higher in white than in amber or orange light, it therefore seems probable that the enhancement of shoot elongation as a response to decreased $\mathrm{B}: \mathrm{PPF}$ at constant $\mathrm{PPF}$ and $\mathrm{R}: \mathrm{FR}$ was mediated by a specific blue-light photoreceptor and not by phytochrome. On the other hand, Expt. III (Tables 3 and 4) demonstrated that, as in tobacco (Kasperbauer, 1971), radish (Proctor, 1973), and chrysanthemum (Rajapakse et al., 1993), phytochrome is also involved in stem elongation of roses, as EOD-FR induced a stimulation of shoot elongation, which was red light reversible. Therefore, these findings suggest that the reduction of plant height observed in plants grown under $\mathrm{CuSO}_{4}$ filters is likely to be mediated by phytochrome and a blue-light receptor.

The increase in stem elongation resulting from amber, orange, and EOD-FR light was accompanied by a shift in dry matter distribution between the leaves and the stem of the shoots. Shoots grown in these light qualities partitioned more dry weight into stems than into leaves (Table 4). Amber, orange, and EOD-FR light had a similar effect on shoot elongation and dry weight partitioning within upper and lower shoots; however, the effect on flower development differed. Amber and orange only slightly affected the number of flowering shoots per plant. The small increase in the percentage of flowering upper shoots in orange light was compensated by a decrease in the number of flowering lower shoots. However, EOD-FR strongly reduced flowering of upper and lower shoots. As the general growth pattern of shoots a response to amber and orange light or EOD-FR was similar, it seems unlikely that it is only the amount of assimilates imported by the shoots that determines whether abortion or full development of a flower bud will take place. To clarify the role of assimilate availability on flower development during various stages of shoot growth, the transport of assimilates to the apex or flower bud itself should be studied instead of the overall import by the shoots.

Light-quality-controlled stem elongation may be mediated by gibberellins, as this plant growth regulator is involved in the control of stem elongation (Reid et al., 1990). In addition to enhancing stem elongation, gibberellic acid also stimulated flower development in roses (Zieslin and Halevy, 1976; Mor and Zieslin, 1987). Since it has been demonstrated in several plant species that red light influenced gibberellin metabolism (Reid et al., 1968; Campell and Bonner, 1986), it would be interesting to study whether the morphogenetic responses of 'Mercedes' rose to changes in the blue-light content of PPF or EOD-R : FR are mediated by changes in gibberellin metabolism.

Table 4. Ratio of leaf to stem dry weight and total dry weight of the upper and lower shoots of 'Mercedes' rose.

\begin{tabular}{|c|c|c|c|c|}
\hline \multirow{2}{*}{$\begin{array}{l}\text { Light } \\
\text { quality }^{2}\end{array}$} & \multicolumn{2}{|c|}{ Upper shoot } & \multicolumn{2}{|c|}{ Lower shoot } \\
\hline & Dry wt $(g)^{y, x}$ & Leaf : stem & Dry wt (g) & Leaf : stem \\
\hline \multicolumn{5}{|l|}{ Experiment I } \\
\hline White 90 & $1.16 \mathrm{a} \pm 0.15$ & $3.4 \mathrm{a} \pm 0.3$ & $0.37 \mathrm{a} \pm 0.29$ & $3.8 \mathrm{a} \pm 0.5$ \\
\hline White 18 & $2.08 \mathrm{~b} \pm 0.13$ & $3.4 \mathrm{a} \pm 0.3$ & $1.41 \mathrm{~b} \pm 0.30$ & $3.9 \mathrm{a} \pm 0.3$ \\
\hline White 27 & $2.31 \mathrm{~b} \pm 0.35$ & $3.5 \mathrm{a} \pm 0.1$ & $1.72 b \pm 0.36$ & $4.0 \mathrm{a} \pm 0.2$ \\
\hline \multicolumn{5}{|l|}{ Experiment II } \\
\hline White & $1.36 \mathrm{a} \pm 0.21$ & $3.5 \mathrm{a} \pm 0.3$ & $0.70 \mathrm{a} \pm 0.04$ & $3.8 \mathrm{a} \pm 0.2$ \\
\hline Amber & $1.43 a b \pm 0.35$ & $2.4 \mathrm{~b} \pm 0.4$ & $0.87 \mathrm{ab} \pm 0.50$ & $3.2 b \pm 0.3$ \\
\hline Orange & $1.81 \mathrm{~b} \pm 0.07$ & $2.4 \mathrm{~b} \pm 0.2$ & $0.86 \mathrm{~b} \pm 0.03$ & $2.6 \mathrm{c} \pm 0.2$ \\
\hline \multicolumn{5}{|l|}{ Experiment III } \\
\hline EOD-R & $1.27 \mathrm{a} \pm 0.07$ & $3.8 \mathrm{a} \pm 0.2$ & $0.87 \mathrm{a} \pm 0.10$ & $3.9 \mathrm{a} \pm 0.3$ \\
\hline EOD-R/FR & $1.29 \mathrm{a} \pm 0.30$ & $3.1 \mathrm{~b} \pm 0.1$ & $0.87 \mathrm{a} \pm 0.22$ & $3.3 \mathrm{a} \pm 0.3$ \\
\hline EOD-FR/R & $1.31 \mathrm{a} \pm 0.23$ & $3.8 \mathrm{a} \pm 0.1$ & $0.77 \mathrm{a} \pm 0.19$ & $3.8 \mathrm{a} \pm 0.2$ \\
\hline
\end{tabular}

Light conditions were as described in Tables 1 and 2.

'Weights were determined 4 weeks after the start of the light treatment and represent the means of three measurements with three plants in each ( \pm SD).

${ }^{x}$ Values of the same light treatment and plant part followed by different letters are significantly different $(t$ test, $P<0.05)$. 


\section{Literature Cited}

Cockshull, K.E. 1975. Roses II: The effects of supplementary light on winter bloom production. J. Hort. Sci. 50:193-206.

Campell, B.R. and B.A. Bonner. 1986. Evidence for phytochrome regulation of gibberellin $\mathrm{A}_{20} 3 \beta$-hydroxylation in shoots of dwarf (lele) Pisum sativum L. Plant Physiol. 82:909-915.

Gaba, V. and M. Black. 1983. The control of cell growth by light, p. 358400. In: W. Shropshire, Jr., and H. Mohr (eds.). Encyclopedia of plant physiology. new series. vol. 16A. Photomorphogenesis. Springer Verlag, Berlin.

Hand, D.W. and K.E. Cockshull. 1979. The effect of $\mathrm{CO}_{2}$ concentration on the canopy photosynthesis and winter bloom production of the glasshouse rose 'Sonia' (syn. 'Sweet Promise'). Acta Hort. 51:243-252.

Horridge, J.S. and K.E. Cockshull. 1974. Flower initiation and development in the glasshouse rose. Sci. Hort. 2:273-284.

Hughes, J. E., D.C. Morgan, P.A. Lambton, C.R. Black, and H. Smith. 1984. Photoperiodic signals during twilight. Plant Cell Environ. 7:269277.

Kasperbauer, M.J. 1971. Spectral distribution of light in tobacco canopy and effects of end-of-daylight quality on growth and development. Plant Physiol. 47:775-778.

Kasperbauer M. J., P.G. Hunt, and R.E. Sojka. 1984. Photosynthate partitioning and nodule formation in soybean plants that received red or far-red light at the end of the photosynthetic period. Physiol. Plant. 61:549-554.

Khosh-Khui, M. and R.A.T. George. 1977. Responses of glasshouse roses to light conditions. Sci. Hort. 6:223-235.

Lagarias, J. C., J.M. Kelly, K.L. Cyr, and W.O. Smith. 1987. Comparative photochemical analysis of highly purified 124-kilodalton oat and rye phytochrome in vitro. Photochem. Photobiol. 46:5-13.

Meijer, G. 1959. The spectral dependence of flowering and elongation. Acts Bet. Neerl. 8: 189-246.

Mor, Y. and A.H. Halevy. 1984. Dual effect of light on flowering and sprouting of rose Rosa hybrida cultivar Marimba shoots. Physiol. Plant. $61: 119-124$

Mor, Y. and N. Zieslin. 1987. Plant growth regulators in rose plants. Hort. Rev. 9:53-73.

Mor, Y., H. Spiegelstein, and A.H. Halevy. 1981. Translocation of ${ }^{14} \mathrm{C}-$ assimilates in roses. II. The effect of shoot darkening and cytokinin application. Physiol. Plant. 52: 197-200.

Mortensen, L.M. and E. Strømme. 1987. Effects of light quality on some greenhouse crops. Sci. Hort. 33:27-36.

Mortensen, L. M., H.R. Gislerød, and H. Mikkelsen. 1992. Effects of different levels of supplementary lighting on the year-round yield of cut roses. Gartenbauwissenschaften 57:198-202.

Proctor J.T.A. 1973. Developmental changes in radish caused by brief end-of-day exposures to far-red radiation. Can. J. Bet. 51:1075-1077.

Rajapalcse N.C. and J.W. Kelly 1992. Regulation of chrysanthemum growth by spectral filters. J. Amer. Soct. Hort. Sci. 117:481-485.

Rajapakse N.C. and J.W. Kelly 1994. Influence of spectral filters on growth and postharvest quality of potted miniature roses. Scientia Hort. 56:245-255.

Rajapakse N. C., M.J. McMahon, and J.W. Kelly 1993. End of day far-red light reverses height reduction of chrysanthemum induced by CUSO, spectral filters. Scientia Hort. 53: 249-259.

Reid, D.M,., J.B. Clements, and D.J. Carr. 1968. Red light induction of gibberellin synthesis in leaves. Nature 217:580-582.

Reid, J. B., O. Hasan, and J.J. Ross. 1990. Internode length in Pisum. Gibberellins and the response to far-red light. J. Plant Physiol. 137:4652.

Smith, H. 1994. Sensing the light environment the functions of the phytochrome family, p. 377-416. In: R.E. Kendrick and G.H.M. Kronenberg (eds,). Photomorphogenesis in plants. 2nd ed.Kluwer Academic Publishers, Dordrecht.

Steiner, A.A. 1984. The universal nutrient solution, p. 633-649. In: International Society for Soilless Culture. Proceedings of the Sixth International Congress on Soilless Culture, Lunteren, The Netherlands. Pudoc, Wageningen.

Thomas, B. and H.G. Dickinson. 1979. Evidence for two photoreceptors controlling growth in de-etiolated seedlings. Planta 146:545-550.

Warrington, LJ. and K.J. Mitchell. 1976. The influence of blue- and redbiased light spectra on the growth and development of plants. Agr. Metereol. 16:247-262.

Zieslin, N. and A.H. Halevy. 1976. Flower bud atrophy in Baccara roses. V. The effect of different growth substances on flowering. Physiol. Plant. 37:326-330.

Zieslin, N. and R. Moe. 1985. Rosa, p. 214-225. In: A.H. Halevy (cd.). Handbook of flowering. vol 4. CRC Press, Boca Raton, Fla. 